\title{
Job Satisfaction Affecting Cross-Cultural Adjustment in Taiwanese Expatriates
}

\author{
Chiu-yi (Pei-Chen) Lee \\ Victoria University, Australia
}

\begin{abstract}
By means of the increasing global competition and internationalization of world markets, international expatriates assignments are more and more essential to successful worldwide development for many multinational corporations. Therefore, international expatriates are imperative to the survival of globe enterprises in the twenty-first century. Expatriates can become an important human resource to international enterprises or multinational operations. Also, for the past two decades, research has examined a variety of correlates for the performance problems and dissatisfaction associated with global assignment. To facilitate business expatriates adjust to an overseas environment and work effectively, Multinational Corporations (MNCs) need to recognise the expatriates' job satisfaction factor to affect cross-cultural adjustment. The main purpose of this study is utilising previous researcher Lee's (2002) questionnaire to investigate the relationship between the job satisfaction and cross-cultural adjustment of Taiwanese Banks' expatriates assigned to America, and this study employed same questionnaire to examine the relationship between the job satisfaction and cross-cultural adjustment of Taiwanese expatriates in several different industries assigned to Mainland China. Also, the empirical outcomes were compared between Taiwanese expatriates located in Mainland China and United States.

In examining the significant degree of Taiwanese expatriates assigned to Mainland China, the instrument was a questionnaire survey conducted to this study. The variables of interest were measured using items Likert-type questions, and those items are divided into seven categories. Data collected from 353 participants who have experience of a posting to Mainland China for international assignments. Multiple regression and correlation were employed to analyse data.

The statistical results of this study were compared Lee's (2002) research that associated with Taiwanese banking expatriates in United States. Both studies indicated that the expatriates' job satisfaction factor to affect cross-cultural adjustment without doubt. This thesis concludes with suggestions for both international enterprises or MNCs and individual expatriate who operate overseas journey in their normal path of business.
\end{abstract}

\section{Introduction}

In the current climate of rapid globalisation, expatriation has been an important element of international business operations. Parent companies often send expatriates abroad as corporate representatives and

Copyright (C) 2006 Victoria University. This document has been published as part of the Journal of Business Systems, Governance and Ethics in both online and print formats. Educational and non-profit institutions are granted a nonexclusive licence to utilise this document in whole or in part for personal or classroom use without fee, provided that correct attribution and citation are made and this copyright statement is reproduced. Any other usage is prohibited without the express permission of the ambassadors (Gregersen et al., 1996). Usually, moving people out of the parent company to work in a foreign subsidiary appears to serve three main purposes: filling staff vacancies, management development and organisational development (Edstrom and Galbraith, 1997; Tung, 1982; Ondrack, 1985). For these strategic reasons, despite the problems and costs (eg. Kobrin, 1998; 
Boyacigiller, 1990), and suggestions of reduced dependence on expatriates (Adler and Bartholomew, 1992; Kobrin, 1998; Schuler, Fulkerson and Dowling, 1991), expatriation is likely to continue.

Much of the expatriate management literature on this topic has focused on the management of crosscultural adjustment (eg. Harris and Moran, 1989; Berry, Kim and Boski, 1988; Black and Gregerson, 1991). This is because expatriates possibly working in an overseas environment with extremely dissimilar political, cultural and economic conditions often face both job-related and personal problems (Birdseye and Hills, 1995). If ignored, these problems bring about stress and dissatisfaction inside and outside of an expatriate's professional life and may lead to staff turnover. Indeed, failure rates of staying among expatriates, measured as those who return prematurely, can reach staggering proportions and be quite costly (Arthur and Bennett, 1995; Cavusgil et al., 1992; Harvey, 1985; Oddou, 1991) not only to the international organisations which transfer the employee and his/her family abroad but also to the expatriates themselves. Furthermore, expatriates who cannot adjust but nevertheless remain on the assignment and perform poorly can be even more damaging to the international organisations than those who return prematurely (Harzing, 1995; Forster, 1997).

Since 1987 an open door policy under the Chinese government has allowed more investment to flow into Mainland China from Taiwan, to the benefit of both countries. At the same time, Taiwan's government deregulated control over foreign exchange and this led to a rapid increase in outward investment by Taiwan's enterprises. Economic relations between Taiwan and China have developed rapidly. In earlier days, only a few people wanted to be assigned to work in Mainland China. But nowadays, following the increasing investment, many more people volunteer to develop their careers in Mainland China for a longer period. Due to the high costs associated with failures and poor overseas performance, MNCs need to ensure that the executives they post to foreign assignments have successful experiences. In order to reach the successful goal, MNCs need to comprehend the correlates and consequences of expatriate' job satisfaction. With this in mind, the purpose of the study reported here was to examine the relationships, this study investigate the effect of job satisfaction on cross-cultural adjustment by using a sample of expatriates in Mainland China.

\section{Literature Review}

\section{Job Satisfaction}

Job satisfaction is the extent an employee feels negatively or positively about his/her job (Odom et al., 1990). Black et al. (1991) pointed to the importance of job factors for both degree and mode of adjustment. Job satisfaction is one of the predicted outcomes of cross-cultural adjustment; it can be defined as the positive emotional state resulting form the overall evaluation of one's job (Shaffer and Harrison, 1998).

In a study on relocation attitudes and work adjustment, Fisher and Shaw (1994) demonstrated that satisfaction was an outcome of expatriates' adjustment. Feldman and Tompson (1993) determined that various corporate career development programs contributed significantly to several aspects of employee satisfaction. One such practice was ensuring that the expatriate assignment fitted in with the employee's overall career plan. Furthermore, providing mentors as well as opportunities for employees to develop new skills, was significant to expatriate satisfaction.

\section{Cross-cultural Adjustment}

Cross-cultural adjustment is generally defined as the process of adaptation to living and working in a foreign culture. It is the perceived degree of psychological comfort and familiarity a person has with the new host culture (Black, 1988; Mendenhall and oddou, 1987). Several researchers have highlighted factors affecting the process of adjustment. For example, Black, Mendenhall and Oddou (1991) identified anticipatory (before-leaving) and in-country (post-arrival) factors. In addition, they noted work, interactions and general adjustment as three levels of adjustment. Feldman and Tompson (1993) 
identified six sets of factors: demographic variables; the extent of 'internationalness' of the job change; job characteristics variables; amount of organisation support vis a vis assistance and career development; degree of difference between successive job assignments; and types of individual coping strategies. It is possible to classify factors affecting cross-cultural adjustment into two broad types; extrinsic (those relating to the organisation and environment) and intrinsic factors (those relating to the characteristics, psychological and physical, of the individual. Many studies have found that the crucial problem for the expatriate is that adaptation to the unfamiliar culture than with their professional expertise (eg. Aahad and Osman-Gani, 2000; Dowling et al., 1999; McEnery and DesHarnais, 1990; Osland, 1995). Successful adaptation and cultural adjustment not only directly influence expatriates performance but also lead to corporate success in the international stage.

\section{Methodology}

In order to investigate the job satisfaction of Taiwanese expatriates adjustment in Mainland China, the study was adopted quantitative research approach, where the quantitative research approach will then be employed to test the hypotheses.

\section{Sample}

The target population of this study was 1,786 Taiwanese manufacturing firms located in Shanghai. Shanghai is the most developed city of east China and many Taiwanese investors set up their manufacturing company in here. This study used a stratified sampling procedure based on type of industry to select the sample. There are 20 different categories of industries such as food industry, plastics industry, cement industry, spinning and weaving, electric machinery, electric equipment and so on included in these 1,786 firms. Ten companies were selected from each industry by using a random numbers table. Therefore, there a total of 200 firms were selected from the address book that is issued by the Straits Exchange Foundation of Taiwan. Non-response was managed by replacement. In this study, the respondents targeted are one expatriate in the each firm.

\section{Statistics Analysis}

All of statistical data analyses were performed using SPSS (Statistical Package for Social Science) for Windows. The analysis used Correlation Coefficient; Descriptive statistics methods were used to describe the sample and inferential statistics to draw conclusions about the theoretical model.

\section{Correlation Coefficient}

Correlation coefficients were computed between the job satisfaction and cross-cultural adjustment. The correlation coefficient was used to describe directions and strengths between the independent variable and the dependent variable.

\section{Research Results}

Total of 1200 questionnaires initially mailed to Taiwanese business expatriates in Shanghai and followed-up by e-mail. Total responses were 353, but there were 22 invalid questionnaires. As a result, total response 353 minus the invalid questionnaires 22; therefore, 331 returned surveys were usable. The percentage of valid questionnaires was 27.58 percent. Table 1 also showed the Standard Deviation of job satisfaction was 0.6916 .

This section of the study, through regression analysis investigated the influence of job satisfaction on cross-cultural adjustment through the stepwise method.

Because stepwise regression was requested, SPSS first investigated a model with the correlated independent variable job satisfaction, as demonstrated in Table 5.3. It also revealed that the partial 
correlation for job satisfaction was 0.501, In effect, independent variable as job satisfaction was significant for explaining the cross-cultural adjustment model. The bi-variate correlation between job satisfaction and cross-cultural adjustment was positive. At the same time, the independent variable was statistically significant as revealed in Table 2 and Table 3 below: Job satisfaction $(\mathrm{P}=0.000<0.05)$. This appeared to verify that the practical predictor in this study for cross-cultural adjustment was job satisfaction. It accounted for 39.44 percent $\left(0.628^{2}\right)$ of the variance of cross-cultural adjustment.

\begin{tabular}{|l|c|c|c|}
\hline & Mean & Std. Deviation & N \\
\hline Cross-cultural Adjustment & 4.5075 & 1.0039 & 331 \\
\hline Job Satisfaction & 3.3541 & .6916 & 331 \\
\hline
\end{tabular}

Table 1: Descriptive Statistics

\begin{tabular}{|c|c|c|c|}
\hline & & Cross-cultural Adjustment & Job Satisfaction \\
\hline $\begin{array}{c}\text { Pearson } \\
\text { Correlation }\end{array}$ & Cross-cultural Adjustment & 1.000 & .628 \\
\hline & Job Satisfaction & .628 & 1.000 \\
\hline Sig. (1-tailed) & Cross-cultural Adjustment & & .000 \\
\hline & Job Satisfaction & .000 & 331 \\
\hline $\mathrm{N}$ & Job Satisfaction & 331 & \\
\hline
\end{tabular}

Table 2: Correlations

\begin{tabular}{|c|c|c|c|c|c|c|c|}
\hline \multirow[b]{2}{*}{ Model } & \multicolumn{2}{|c|}{$\begin{array}{l}\text { Un-standardised } \\
\text { Coefficients }\end{array}$} & \multirow{2}{*}{$\begin{array}{c}\begin{array}{c}\text { Standardised } \\
\text { Coefficients }\end{array} \\
\text { Beta }\end{array}$} & \multirow[b]{2}{*}{$\mathrm{t}$} & \multirow[b]{2}{*}{ Sig. } & \multicolumn{2}{|c|}{$\begin{array}{l}\text { 95\% Confidence } \\
\text { Interval for B }\end{array}$} \\
\hline & B & Std. Error & & & & $\begin{array}{l}\text { Lower } \\
\text { Bound }\end{array}$ & $\begin{array}{l}\text { Upper } \\
\text { Bound }\end{array}$ \\
\hline Constant & -3.860 & .506 & & -7.633 & .000 & -4.855 & -2.865 \\
\hline $\begin{array}{l}\text { Job } \\
\text { Satisfaction }\end{array}$ & .610 & .058 & .420 & 10.441 & .000 & 0.495 & 0.725 \\
\hline & & & \multicolumn{5}{|c|}{ Correlations } \\
\hline \multicolumn{3}{|c|}{ Model } & Zero-Order & \multicolumn{2}{|c|}{ Partial } & \multicolumn{2}{|c|}{ Part } \\
\hline \multicolumn{3}{|c|}{ Job Satisfaction } & 0.628 & \multicolumn{2}{|c|}{0.501} & \multicolumn{2}{|c|}{0.372} \\
\hline
\end{tabular}

Table 3: Coefficients of Proposed Model

a Dependent Variable: CCA (Cross-cultural Adjustment)

\section{Comparison and Discussion}

The results of this study were also compared with Lee's (2002) research shown in Table 4. Results were quite not different between Taiwanese located in the United State and Mainland China. In this section, independent variable which was significant in the present study: job satisfaction was statistically significant, and the statistical result of Taiwanese expatriates assigned to Mainland China was compared with the Taiwanese expatriates located in the United States (Lee 2002) as shown in Table 4 below.

\begin{tabular}{|l|c|c|}
\hline \multicolumn{2}{|c|}{ The Significance of the Relationship of Independent Variable to Adjust in Mainland China and } \\
the U.S. \\
\hline & Mainland China & United States * \\
\hline Job Satisfaction & Significant & Significant \\
\hline
\end{tabular}

Table 4: The Significance of the Relationship of Independent Variable to Adjust In Mainland China and the United States (Source: Lee, H.W. 2002, 'A study of Taiwanese banking expatriates in the United

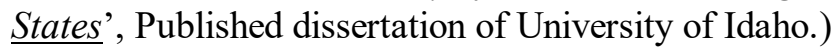


Based on the statistical analysis of this study, the data revealed that the correlation between job satisfaction and cross-cultural adjustment was positive. Similarly, Lee's (2002) research demonstrated that job satisfaction $(\mathrm{r}=0.49, \mathrm{p}<0.05)$ was an important factor in cross-cultural adjustment. Previous research by Black et. al. (1991), Miller (1975) and Shaffer and Harrison (1998) also demonstrated the significance of job satisfaction for adjustment. Thus, job satisfaction was an indispensable factor affecting on cross-cultural adjustment for both Taiwanese expatriates posted to Mainland China and to the United States.

As the overall evaluation or emotional state resulting from the appraisal of one's job or one's experiences, job satisfaction is clearly and primarily work-related. It is presumed to arise from successful adaptation to overseas job requirements and from effective development of interpersonal relationships within the host country's workforce and customers. If maladjustment is equated with stress, then it is an aversive psychological state that will create negative evaluations of and negative affect toward the stimulus that created it. In other words, both work as well as interaction adjustment may result in job satisfaction.

Not surprisingly, work-related factors had the positive relationship to expatriate adjustment. A possible explanation is that expatriate international assignments usually require considerable responsibility and autonomy and are often marred by policy and procedural conflicts that occur between the parent company and its overseas performance. Undeniably, it makes sense that ambiguity, discretion and conflict will influence the capability of expatriates to adjust to their new work assignments overseas.

The findings of this study suggest that to achieve the ideal fit between Taiwanese expatriates and the new work and socio-cultural environment of Mainland China, both the Taiwanese MNCs and expatriates need to comprehend the influence of job satisfaction factor on the adjustment of individuals. The majority of the respondents considered that the cross-cultural adjustment of Taiwanese expatriates in Mainland China was affected by job satisfaction. Job satisfaction factor indeed facilitated the adjustment of Taiwanese expatriates assigned to Mainland China.

It appears that, Taiwanese MNCs must cooperate with affiliates and involve their management in the recognising the key influence of this factor on adjustment. Furthermore, Taiwanese MNCs must provide continuous support to the employees throughout their assignment in their Mainland China assignment.

\section{Conclusion}

Job Satisfaction with the expatriation experience is an important determinant of an expatriate's success in overseas assignments.

Job satisfaction is defined as a pleasurable feeling that results from the perception that one's job is fulfilling, or allows for fulfillment. According to this definition, the existence of this can mean that workers with higher job satisfaction have less intention to leave their jobs. If expatriates are not satisfied while on assignment, the motivation to perform well and/or to remain abroad for the specified length of time is diminished. Referring to the findings of this study the data indicated that job satisfaction of Taiwanese business expatriates obviously affected their cross-cultural adjustment to Mainland China. Similarly, job satisfaction was the significant factor affecting the cross-cultural adjustment of Taiwanese assigned to both Mainland China and the United States.

In today's challenging global arena, the finding of this study offers positive ideas for improving the retention of employees to multinational organisations developing expatriates to Mainland China and elsewhere. The successful management of expatriation process will continue to be an important human resource challenge facing companies in the next millennium. 


\section{Bibliography}

Adams, G.A. King, L.A. and King, D.W. 1996, 'Relationships of job and family involvement, family social support, and work-family conflict with job and life satisfaction', Journal of Applied Psychology, Vol.18, No.4, pp.411-420.

Andreason, A.W., 2003 (Spring), 'Expatriate adjustment to foreign assignments', International Journal of Commerce and Management, Vol.13, No.1, pp.42-53.

Answer, 2005, online, Geography of China, reviewed 27 August 2004, http://www.answers.com/topic/china

Arthur, W. and Bennett, W. 1995, 'The international assignee: the relative importance of factors perceived to contribute to success', Personnel Psychology, Vol. 48: pp.99-114.

Ashford, S. and Taylor, M. 1990, 'Adaptations to Work Transitions: An Integrative

Approach', in K. Rowland and G. Ferris. Research in Personnel and Human Resources, Greenwich, CT: JAI Press.

Babajeva, E., Romanovska, I. and Allerstorfer, T. Fall 2001, 'Chinese Overseas Networks - Taiwanese FDI into Mainland China', The Chinese Challenge in the $21^{\text {st }}$ Century, CEMS workshop, term paper.

Bennet, R., Gorman, H.O. 1998, 'Benchmark with the best', HRM Magazine, Vol.43: 19-22.

Bhagat, R.S. 1983, 'Effects of stressful life events on individual performance effectiveness and work adjustment process within organizational settings: a research model', Academy of Management Review, Vol.8, No.4, pp. 660-671.

Bhuian, S.N. and Abdual-Muhmin, G.G. 1997, 'Job satisfaction and organizational commitment among 'guest-worker' salesforces: The case of Saudi Arabia', Journal of Global Marketing, Vol.10, No.3, pp. 27-43.

Bird, A. and Dunbar, R., 1991, 'Getting the job done over there: Improving expatriate productivity', National Productivity Review, Spring, pp.145-156.

Birdseye, M.G. and Hill, J.S. 1995, 'Individual, organizational/work and environmental influences on expatriate turnover tendencies: and empirical study', Journal of International Business Studies, Vol.26, No.4, pp.787-813.

Black, J.S. 1988, 'Work role transitions: a study of American expatriate managers in Japan', Journal of International Business Studies, Vol.19: pp.277-294.

Brett, J.M. 1980, 'The effects of job transfer on employees and their families', In

Cooper, C.L., Payne, R.(Eds.), Current Concerns in Occupational Stress, Wiley Chichester, U.K.

Caliguri, P.M., Hyland, M.M., Joshi, A., and Bross, A.S. 1998, 'Testing a theoretical model for examining the relationship between family adjustment and expatriates' work adjustment', Journal of Applied Psychology, Vol.83, pp.598-614.

Chautong, N.Y. 2001, 'An excursion into the relationship between Taiwan and China', www.wufi.org.tw.

Dowling, P.J., Welch, D.E. and Schuler, R.S. 1999, International Human Resource Management, South-Western.

Dowling, P., Schuler, R. and Welch, D. 1994, 'International Dimensions of Human Resource Management', 2nd edn, Wadsworth, California.

Downs, M., Thomas, A.S. and Singley, R.B. 2002, 'Predicting expatriate job satisfaction: the role of firm internationalization', Career Development International, Vol.7, No.1, pp.24-36.

Fishman, S.R. 1996, 'Developing a global workforce', Canadian Business Review, Vol.23, pp.18-21.

Frone, M.R., Yardley, J.K. and Markel, K.S. 1997, 'Developing and testing an integrative model of the work-family interface', Journal of Vocational Behavior, Vol.50, pp.145-167.

Kanter, R.M., 1977, Work and family in the United States: a critical review and agenda of research policy, Russel Sage Foundation, New York:

Kao, C. 2001, 'The effect on the Taiwanese economy of manufacturing investment in Mainland China in operating locally', Quarterly Publication of Economical Situation and Comment, Vol.7, No.1.

Lee, H.W. 2002, A study of Taiwanese banking expatriates in the United States, Published dissertation of University of Idaho. 
Locke, E.A. 1976, 'The nature and causes of job satisfaction', In M.Dunnette (ed.), Handbook of Industrial and Organizational Psychology, Rand McNally, Chicago.

Lu, L. and Cooper, C.L. 1995, 'The impact of job relocation: Future research', Trends in Organizational Behavior, Vol.2, pp. 51-63.

McEvoy, G.M. and Parker, B. 1995, 'Expatriate adjustment: causes and consequences', in Selmer, J. (ed.) Expatriate Management: New Ideas for International Business, Quorum Books, Westpoint, CT, pp.97-114.

McGoldrick, F. 1997, 'Expatriate compensation and benefit practices of U.S. and Canadian firms: Survey results', International HR Journal, Summer: pp.13-17.

Melvin, S. 2001, 'Retaining Chinese employees', China Business Review, November-December, pp.3543.

Ministry of Economic Affairs (MOEA), 2002, The Investigation Report on the Outward Investment by Manufacturing Industry, Taiwan.

Ministry of Economic Affairs (MOEA) (1997), The Investigation Report on the Outward Investment by Manufacturing Industry (in Chinese), Taiwan.

---- (1998), The Investigation Report on the Outward Investment by Manufacturing Industry (in Chinese).

---- (1999), 'Table A-12 The Growth Rate of the Industrial Output in Major Countries' (in Chinese), http://www.moea.gov.tw/ meco/stat/four/a-12.htm.

---- (2000), 'The Role of Service Industry in Economic Development' (in Chinese), http://www.moea.gov.tw/ meco/paper/issue/15.htm.

Ministry of Finance (MoF) (Taiwan) (1993), Report on the Characteristic Classifications of Tradeable Commodities.

---- (1998), Monthly Statistics of Exports and Imports, December 1998.

Muchinsky, P.M. and Tuttle, M.L. 1979, 'Employee Turnover: An empirical and methodological assessment', Journal of Vocational Behavior, Vol.14, pp.43-47.

Munton, A. and Foster, N. 1993, Job Relocation: Managing People on the Move, Wiley, London.

Naumann, E. 1993, 'Antecedents and consequences of satisfaction and commitment among expatriate managers', Group and Organization Management, Vol.18, No.2, pp.153-187.

Naumann, E. 1993, 'Organisational predictors of expatriate job satisfaction', Journal of International Business Studies, Vol.10, No.1, pp.61-80.

Negy, C. and Woods, D.J. 1992, 'The importance of acculturation in understanding research with Hispanic-American', Hispanic Journal of Behavioral, Vol.14, pp.224-247.

Osland, J.S. 1995, 'Working Abroad: A hero's adventure', Training and Development Journal, Vol.49, No.11, pp.47-51.

Pinder, C.C. and Das, H. 1979, 'Hidden costs and benefits of employee transfers', Human Resource Planning, Vol.2, pp.135-145.

Schak, D.C. 1997, 'Taiwanese labour management in China', Vol.19, No.4, pp.365-373.

Schneider, S.C. and Asakawa, K. 1995, 'American and Japanese expatriate adjustment: a psychoanalytic perspective', Human Relations, Vol.48, pp.1109-1127.

Schuler, R., Fulkerson, J., and Dowling, P. 1991, 'Strategic Performance Measurement and Management in Multinational Corporations', Human Resource Management, Vol.30, pp.365-392.

Sergeant, A. and Frenkel, S. 1998, 'Managing people in China: perceptions of expatriate managers', Journal of World Business, Vol.33, No.1, pp.17-34.

Shaffer, M.S. and Harrison, D.A. 1998, 'Expatriate's psychological withdrawal from international assignments: Work, non-work, and family influences', Personnel Psychology, 51: 87-118.

Shear, E.B. 1993, 'Strange encounters: a communication model for cross-cultural adaptation and training', UMI Dissertation Services. Ann Arbor. MI.

Stening, B.W. and Hammer, M.R. 1992, 'Cultural baggage and the adaption of expatriate American and Japanese managers', Management International Review, Vol.32, No.1, pp.77-89.

Stroh, LK., Brett, JM. and Reilly, AH. 1992, 'What may be obvious may not be true: a non-recursive model predicting manager and spouse international willingness to relocate', Paper presented at the $52^{\text {nd }}$ Annual Meeting of the Academy of Management, Las Vegas. 
Tan, Q. 2000, 'Democratization and bureaucratic restructuring in Taiwan', Studies in Comparative International Development, Summer: pp.48-64.

Taylor, S. and Napier, N. 1996, 'Working in Japan: lessons from Western expatriates', Sloan Management Review, Vol.37, pp.76-84.

Tung, C.Y. 2004, Economic relation between Taiwan and China, UNISCI discussion papers, Taiwan.

Tung, R.L. and Miller, E.L. 1990, 'Managing in the twenty-first century: The need for global orientation', Management International Review, Vol.30, pp.5-18.

Yavas, U. and Bodur, M. 1999, 'Satisfaction among expatriate managers: correlates and consequences, Career Development International, Vol.4, No.5, pp.261-269.

Ying, Y.W., 1996, 'Immigration satisfaction of Chinese Americans: An empirical examination', Journal of Community Psychology, Vol.24, pp.3-15. 